\title{
Another Window: The Term Auction Facility
}

\author{
David C. Wheelock
}

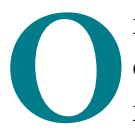
n December 12, 2007, the Federal Reserve and four other central banks announced they were taking measures to alleviate pressures in short-term financial markets. One measure the Federal Reserve instituted was the establishment of a temporary Term Auction Facility (TAF), designed to lend funds directly to depositiory institutions for a fixed term (thus far, for 28 or 35 days). Two auctions of term loans were held in December, two were held in January 2008, and two more were held in February 2008. Although the TAF is a temporary program, the Fed announced that it is considering a permanent facility for auctioning term credit. ${ }^{1}$

The TAF was created in part because the volume of discount window borrowing has remained low despite persistent stress in interbank lending markets, possibly because of a perceived stigma associated with such borrowing. Moreover, most discount window loans have been overnight loans, even though restrictions on discount window loans were relaxed on August 17, 2007, to permit loans of up to 30 days. The TAF offers an anonymous source of term funds without the stigma attached to discount window borrowing.

TAF loans are made against any collateral that is normally accepted for discount window loans. However, the operations of the TAF and the discount window program differ in several respects. Traditional discount window loans are made at interest rates set by the Federal Reserve, with no limits on the aggregate volume of loans that can be extended on any given date. By contrast, under the TAF, the Federal Reserve determines in advance the dollar amount of funds it will lend at each auction and the interest rate charged on those loans is determined from the auction itself. ${ }^{2}$ For example, at its auction on December 17, 2007, the Federal Reserve offered \$20 billion with a 28 -day term and received bids totaling $\$ 61.553$ billion. Bids offering the highest interest rates were accepted until the full $\$ 20$ billion had been allocated, though all successful bids were funded at the lowest accepted bid rate (4.65 percent).

Has the TAF helped ease financial market pressures? Short-term financial markets began to show signs of substantial strain in August 2007, as rising U.S. mortgage defaults caused market participants to question the values of asset-backed securities and the net worth of institutions that hold those securities. One indication of the scramble for liquidity, shown in the chart, was a sharp increase in the interest rates offered by banks on one-month bank certificates of deposit relative to the Federal Reserve's federal funds rate target. Although money market pressures eased in September and October, strains in the markets reappeared in November and early December. Once again, term deposit rates rose sharply even though market forecasters expected the Fed to lower its federal funds rate target. Market interest rates generally fell after the December 12 announcement, suggesting that market participants viewed the coordinated central bank action as likely to ease money market pressures, especially during the year-end period when the demand for liquidity typically is high. The impact of the auctions themselves is difficult to determine, however, as seasonal patterns, expectations of future monetary policy actions, and other factors all influence interest rates and other indicators of financial market conditions.

${ }^{1}$ Board of Governors of the Federal Reserve System press release, December 12, 2007: www.federalreserve.gov/newsevents/press/monetary/20071212a.htm.

${ }^{2}$ See www.federalreserve.gov/monetarypolicy/taf.htm.

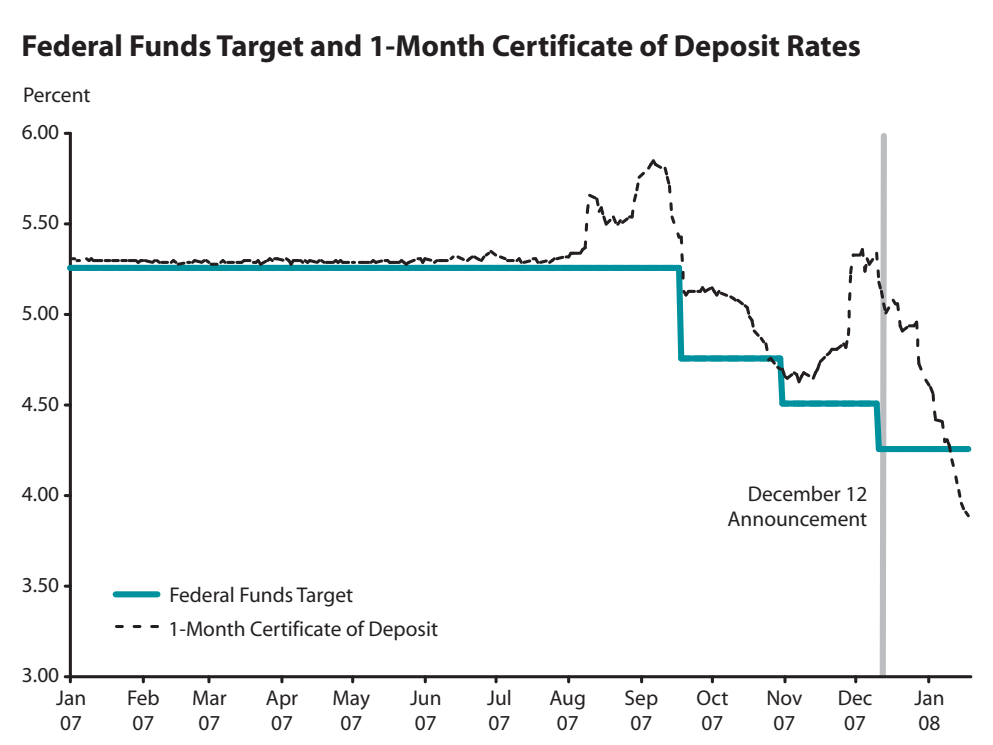

NOTE: Daily Data, January 02, 2007 thru January 18, 2008. 